\title{
MOLECULAR CYTOGENETIC STUDY OF THE NF2 GENE DELETION IN MENINGIOMA IN SUDANESE PATIENTS
}

\author{
AbdElmontalab Farah $\mathrm{Y}^{1}$, Fadl Elmula I ${ }^{2}$, Abushama HM${ }^{1}$, Kreskowski K ${ }^{3}$, Liehr T ${ }^{3, *}$
}

*Corresponding Author: Dr. Thomas Liehr, Institut für Humangenetik, Kollegiengasse 10, D-07740 Jena, Germany; Tel.: 49-3641-935533; Fax: ++49-3641-935582; E-mail: Thomas.Liehr@med.uni-jena.de

\begin{abstract}
Meningioma is the second most common adult central nervous system tumor. Mutations and/or deletions within the tumor suppressor gene neurofibromatosis type $2(N F 2)$ are associated with meningioma development and progression. We studied 29 meningioma samples by cytogenetic analysis and interphase fluorescence in situ hybridization (I-FISH) using a locus-specific probe for the NF2 gene region. We detected loss of the $N F 2$ gene in all samples except for one. In 10 of the 29 samples, karyotypic analyses confirmed the I-FISH results and revealed additional numerical and/or structural rearrangements in nine of them. Our study confirmed: $i)$ the limited role of banding cytogenetics in assessing chromosomal rearrangements in meningioma, as this tumor is hard to be grown in cell culture; ii) we could show that two-color I-FISH is well-suited for NF2-deletion screening. Our results were in accordance with those of comparable studies, even though the frequency of $97.0 \%$ of meningiomas with NF2 deletions is exceptionally high in the studied Sudanese patients.
\end{abstract}

Keywords: Meningioma; NF2 Gene; Tumor suppressor gene; Banding cytogenetics; Interphase fluorescence in situ hybridization (I-FISH); Sudan

\footnotetext{
${ }^{1}$ Zoology Department, Faculty of Science, Khartoum University, Khartoum, Sudan

${ }^{2}$ Faculty of Medicine, Neilein University, Khartoum, Sudan

${ }^{3}$ Jena University Hospital, Friedrich Schiller University, Institute of Human Genetics, Jena, Germany
}

\section{INTRODUCTION}

Meningiomas are benign tumors with a relativey small number of genetic aberrations, accounting for $\sim 1 / 3$ of all primary brain tumors, are the second most common adult central nervous system tumors and occur in up to $1.5 \%$ of the general population; they are most frequently observed in the sixth decade of life [1-2]. Early cytogenetic studies showed complete or partial monosomy 22 as the most common chromosomal abnormality [1,3]. Later studies revealed a tumor suppressor gene on chromosome 22 , sub-band q12.2, to be involved in meningioma formation and progression. Loss of the neurofibromatosis type 2 (NF2) gene is important in early development of meningioma [4], and plays a major role in familial meningioma which account for only $\sim 2.0 \%$ of the cases [1-2]. Small insertions, deletion or single base pair mutations of the $N F 2$ gene are present in $\sim 60.0 \%$ of sporadic meningiomas [5]. Such deletions or mutations of NF2 have been observed in $>70.0 \%$ of grade II or III meningiomas, but in only $25.0 \%$ of grade I meningiomas [1]. We here report on the investigation of cytogenetic aberrations in meningioma among Sudanese patients using banding cytogenetics and molecular cytogenetics.

\section{MATERIALS AND METHODS}

Tumor Samples and Cultivation. This study was approved by the Ethical Review Board at Neilein University, Khartoum, Sudan and informed consent 
was obtained from all patients. Cross-sectional design was used in this study. Twentynine meningioma tissue samples (Table 1) were collected during surgeries from the Alshaab Teaching Hospital located in Khartoum State, Sudan. Thirteen patients were male $(44.8 \%)$ and 16 female (55.2\%), aged 15 to 55 years, thus being much younger than meningioma patients in Western countries. Samples were collected in sterile containers with sterile RBMI-1640 media to be processed for tissue culture within two hours.

Table 1. Results obtained in 29 Sudanese Meningioma Patients.

\begin{tabular}{|c|c|c|c|}
\hline Patient & $\begin{array}{l}\text { Sex- } \\
\text { Age }\end{array}$ & Karyotype & $\begin{array}{c}\text { FISH Result } \\
(\%)\end{array}$ \\
\hline 1 & $\mathrm{~F}-40$ & $45, \mathrm{XX}, \mathrm{t}(6 ; 10)(\mathrm{q} 26 ; \mathrm{q} 26.2),-22$ & $-22(100.0)$ \\
\hline 2 & $\mathrm{~F}-45$ & $45, X X,-22$ & $-22(80.0)$ \\
\hline 3 & $\mathrm{M}-26$ & $44, X Y,-5,-22$ & $-22(90.0)$ \\
\hline 4 & M-26 & $45, \mathrm{XY}, \mathrm{t}(5 ; 11)(\mathrm{q} 35.2 ; \mathrm{p} 13),-22$ & $-22(100.0)$ \\
\hline 5 & $\mathrm{M}-26$ & $45, \mathrm{XY}, \operatorname{del}(8)(\mathrm{q} 22.2 \mathrm{q} 23.3),-22$ & $-22(100.0)$ \\
\hline 6 & M-45 & $44, \mathrm{XY},-14, \mathrm{t}(6 ; 10)(\mathrm{q} 26 ; \mathrm{q} 26.2),-22$ & $-22(100.0)$ \\
\hline 7 & M-50 & $44, X Y,-14,-22$ & $-22(100.0)$ \\
\hline 8 & $\mathrm{~F}-40$ & not available & $-22(90.0)$ \\
\hline 9 & $\mathrm{~F}-52$ & not available & $-22(70.0)$ \\
\hline 10 & $\mathrm{~F}-36$ & not available & $-22(100.0)$ \\
\hline 11 & $\mathrm{~F}-45$ & not available & $-22(70.0)$ \\
\hline 12 & M-15 & not available & $-22(100.0)$ \\
\hline 13 & M-28 & not available & $-22(90.0)$ \\
\hline 14 & $\mathrm{~F}-45$ & not available & $-22(80.0)$ \\
\hline 15 & $\mathrm{M}-18$ & not available & $-22(100.0)$ \\
\hline 16 & $\mathrm{~F}-45$ & not available & $-22(60.0)$ \\
\hline 17 & $\mathrm{M}-20$ & not available & $-22(90.0)$ \\
\hline 18 & $\mathrm{~F}-45$ & not available & $-22(70.0)$ \\
\hline 19 & F-55 & not available & $-22(100.0)$ \\
\hline 20 & M-30 & not available & $-22(70.0)$ \\
\hline 21 & M-45 & not available & $-22(80.0)$ \\
\hline 22 & M-16 & not available & $-22(70.0)$ \\
\hline 23 & M-40 & $45, X Y,-8, \operatorname{del}(22)(q 11 q 13)$ & $\operatorname{del}(\mathrm{NF} 2)(100.0)$ \\
\hline 24 & $\mathrm{~F}-40$ & 46,XX,del(22)(q11q13) & $\operatorname{del}(\mathrm{NF} 2)(100.0)$ \\
\hline 25 & $\mathrm{~F}-37$ & not available & $\operatorname{del}(\mathrm{NF} 2)(100.0)$ \\
\hline 26 & M-52 & not available & $\operatorname{del}(\mathrm{NF} 2)(80.0)$ \\
\hline 27 & F-38 & not available & del(NF2) (90.0) \\
\hline 28 & $\mathrm{~F}-30$ & not available & $\operatorname{del}(\mathrm{NF} 2)(70.0)$ \\
\hline 29 & M-40 & $46, X Y$ & normal (100.0) \\
\hline
\end{tabular}

Cytogenetic and Molecular Cytogenetics. After long-term culture, chromosomes were prepared and GTG-banding was done using standard procedures [6]. Interphase fluorescence in situ hybridization (I-FISH) was performed using a two-color FISH approach: DNA derived from BAC-probe RP11-551L12 was NF2 gene-specific (22q12.2) and labeled with Texas Red; RP11-172D7-DNA located in 22q11.21 served as an internal control and was labeled in SpectrumGreen. The FISH-procedure was done according to standard protocols [7]. For microscopic evaluation, 100 interphase nuclei were examined for each specimen.

\section{RESULTS}

In 10 of the 29 meningioma samples, cell cultivation led to successful karyotyping. The banding cytogenetic results are shown in Table 1.

Representative I-FISH results are shown in Figure 1. In all but one sample, deletions of NF2 were observed, in $60.0-100.0 \%$ of the interphase nuclei studied. In six of the cases the signal pattern indicated an interstitial or terminal deletion of $22 \mathrm{q}$ including the $N F 2$ gene region (Figure 1B), in the other 22 cases the signals indicated the complete loss of a chromosome 22 (Figure 1C, Table 1). Statistical analysis of the $N F 2$ gene deletion against age and gender did not reveal any correlation (results not shown).

\section{DISCUSSION}

In agreement with the literature, the banding cytogenetic approach led to more comprehensive results but was less successful in terms of cell cultivation and growth in almost $70.0 \%$ of the cases $[8,9]$. Besides chromosome 22, involvement of chromosomes 5, 6, 8, 10, 11 and 14 was observed in the present study. Even though involvement of chromosomes 8 and 10 are rather unusual findings [10], chromosome 5, 6, 11 and 14 are known to be involved in menigiomal chromosomal rearrangements [11].

In the present study, statistically there was no significant variation between gender/age and NF2 gene deletion as initiator in tumorigenesis. This might be explained by small samples size, as previous studies demonstrated clear female predominance [12]. However, it may also be an influence of genetic 

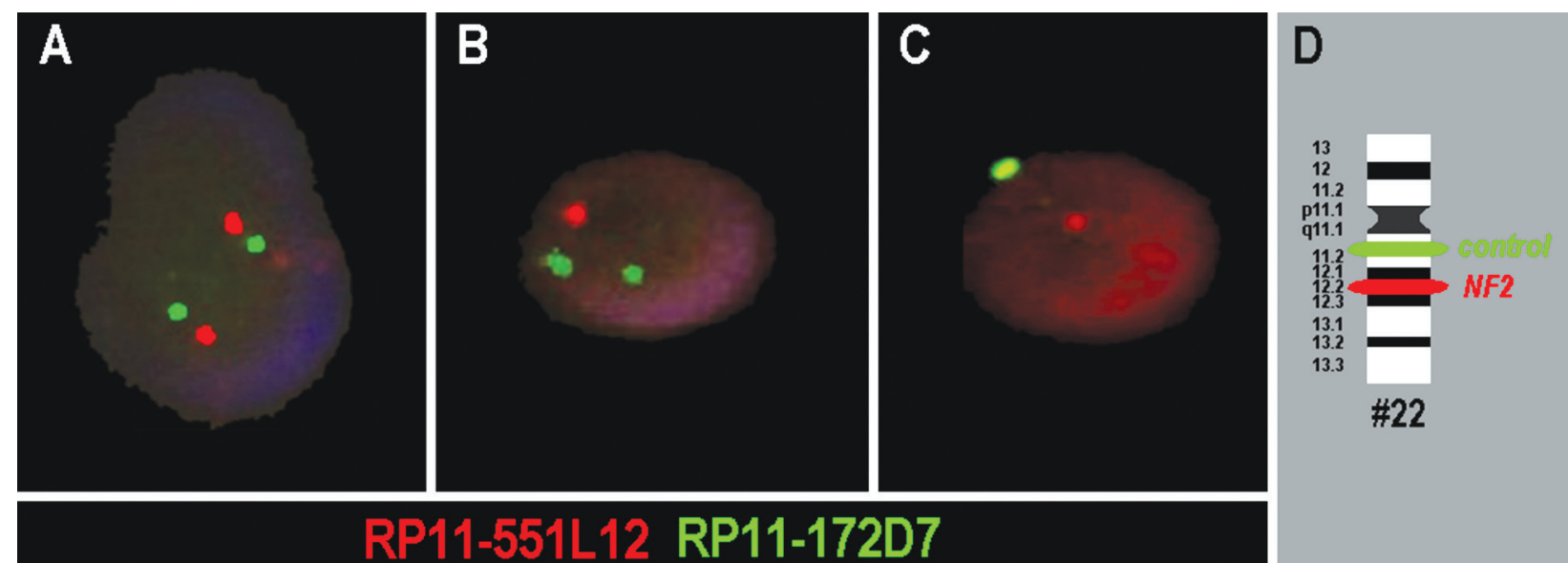

Figure 1. Typical two-color I-FISH results are depicted for three interphase nuclei of the melanoma patients. A) Two signals each in red and green were interpreted as a normal result, indicating the presence of two PROBABLY intact chromosomes 22. B) Loss of one red signal was interpreted as interstitial or terminal loss of chromosome 22q including the NF2 gene region. C) Loss of one red and one green signal were interpreted as mono-somy 22. D) Schematic depiction of the probes and their localization on chromosome 22 (\#22).

background of Sudanese patients; a comparable rate of $97.0 \%$ of meningiomas with NF2 deletions has not yet been found in other ethnicities. Two points that would need more comparison studies for clarification, as comparable studies found loss of NF2 only in $\sim 60.0 \%$ of the studied patients [13]. This may have different reasons such as small sample size. However, neither an influence of ethnic background nor of young age of the studied patients (on average $\sim 37$ years) can be neglected. This study shows that even in known clinical entities more studies especially from African countries are necessary.

\section{ACKNOWLEDGMENTS}

This study was supported in part by the Central Laboratory, Ministry of Science and Technology and Ministry of Higher Education of Sudan.

Declaration of Interest: The authors report no conflicts of interest. The authors alone are responsible for the content and writing of this article.

\section{REFERENCES}

1. Zang KD. Meningioma: a cytogenetic model of a complex benign human tumor, including data on 394 karyotyped cases. Cytogenet Cell Genet. 2001; 93(3-4): 207-220.
2. Wiemels J, Wrensch M, Claus EB. Epidemiology and etiology of meningioma. J Neurooncol. 2010; 99(3): 307-314.

3. Zank1 H, Zang KD. Correlations between clinical and cytogenetical data in 180 meningiomas. Cancer Genet Cytogenet. 1980; 1(1): 351-356.

4. Louis DN, Ramesh V, Gusella JF. Neuropathology and molecular genetics of neurofibromatosis 2 and related tumors. Brain Pathol. 1995; 5(2): 163-172.

5. Capodano AM. Nervous system: meningioma. Atlas Genet Cytogenet Oncol Haematol. July 2000 (http://Atlas GeneticsOncology.org/Tumors/meningiomasID5014. html).

6. Verma RS, Babu A. Human Chromosomes: Principles and Techniques: A Manual of Basic Techniques. New York: McGraw-Hill Professional, 1995.

7. Liehr T. Fluorescence In Situ Hybridization (FISH) Application Guide. Berlin: Springer, 2009.

8. Al-Mefty O, Kadri PA, Pravdenkova S, Sawyer JR, Stangeby C, Husain M. Malignant progression in meningioma: documentation of a series and analysis of cytogenetic findings. J Neurosurg. 2004; 101(2): 210-218.

9. Espinosa $\mathrm{AB}$, Tabernero MD, Maíllo A, Sayagués JM, Ciudad J, Merino M, et al. The cytogenetic relationship between primary and recurrent 
meningiomas points to the need for new treatment strategies in cases at high risk of relapse. Clin Cancer Res. 2006; 12(3 Pt 1): 772-780.

10. Griffin CA, Hruban RH, Long PP, Miller N, Volz P, Carson B, et al. Chromosome abnormalities in meningeal neoplasms: do they correlate with histology? Cancer Genet Cytogenet. 1994; 78(1): 46-52.

11. Lekanne Deprez RH, Riegman PH, van Drunen E, Warringa UL, Groen NA, Stefanko SZ, et al. Cytogenetic, molecular genetic and patho- logical analyses in 126 meningiomas. J Neuropathol Exp Neurol. 1995; 54(2): 224-235.

12. Sondak VK, Swetter SM, Berwick MA. Gender disparities in patients with melanoma: breaking the glass ceiling. J Clin Oncol. 2012; 30(18): 2177-2178.

13. Shen Y, Nunes F, Stemmer-Rachamimov A, James M, Mohapatra G, Plotkin S, et al. Genomic profiling distinguishes familial multiple and sporadic multiple meningiomas. BMC Med Genomics. 2009; 2: 42 